\title{
Reliability and validity of a semi-quantitative FFQ for sodium intake in low-income and low-literacy Brazilian hypertensive subjects
}

\author{
Maria-Carolina S Ferreira-Sae ${ }^{1}$, Maria-Cecilia BJ Gallani ${ }^{1, *}$, Wilson Nadruz Jr², \\ Roberta CM Rodrigues ${ }^{1}$, Kleber G Franchini ${ }^{2}$, Poliana C Cabral ${ }^{3}$ and \\ Maria Lilian Sales ${ }^{2}$ \\ 'Department of Nursing, Faculty of Medical Sciences, University of Campinas, Cidade Universitária 'Zeferino \\ Vaz', 13081-970 Campinas, SP, Brazil: ${ }^{2}$ Department of Internal Medicine, Faculty of Medical Sciences, \\ University of Campinas, Campinas, Brazil: ${ }^{3}$ Nutrition Department of the Health Sciences, Federal University \\ of Pernambuco, Recife, Brazil
}

Submitted 15 April 2008: Accepted 23 March 2009: First published online 28 May 2009

\begin{abstract}
Objective: To assess the reliability and validity of an FFQ to evaluate dietary patterns of $\mathrm{Na}$ consumption among low-income and low-literacy Brazilian hypertensive subjects.

Design: The initial FFQ was submitted to content analysis with the pre-test administered to fifteen subjects. Reliability was evaluated according to the reproducibility criterion, with interviewer administration of the FFQ twice within a $15 \mathrm{~d}$ interval. Validity was assessed against a $24 \mathrm{~h}$ recall (132 subjects), a $3 \mathrm{~d}$ diet record (121 subjects) and a biomarker ( $24 \mathrm{~h}$ urinary Na; 121 subjects). To test the correlation with the biomarker, discretionary salt was added to the FFQ Na values. Setting: A large urban teaching hospital in south-eastern Brazil.

Subjects: The study was based on 132 randomly selected subjects (eighty-three women and forty-nine men) aged 18 to 85 years.

Results: Kappa coefficients ranged from $0 \cdot 79$ to $0 \cdot 98$, confirming the reproducibility of the FFQ. There was no correlation between urinary Na excretion, the FFQ and the $24 \mathrm{~h}$ recall for the general sample, although significant correlations had been observed when methods were summed up $(24 \mathrm{~h}$ recall + discretionary salt + FFQ; $0 \cdot 32, \quad P=0 \cdot 01)$. The addition of discretionary salt significantly improved the biomarker-based FFQ validity, with correlation coefficients varying from $0 \cdot 19$ (general sample) to $0 \cdot 31$ (female sub-sample).

Conclusions: The developed FFQ demonstrated satisfactory evidence of validity and reliability and can be used as an important complementary tool for the evaluation of $\mathrm{Na}$ intake among Brazilian hypertensive subjects.
\end{abstract}

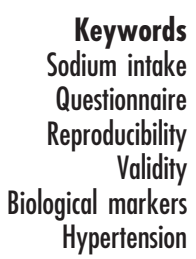

Hypertension is recognized as the number one attributable risk for death from CVD around the world ${ }^{(1)}$. Diet and lifestyle strongly influence all causes of mortality throughout the life $\operatorname{span}^{(2)}$, and dietary patterns play a major role in the development of CVD, especially hypertension $^{(2,3)}$. Evidence shows, however, that $\mathrm{Na}$ restriction is associated with a reduction in the risk of CVD death while high $\mathrm{Na}$ intake increases that risk ${ }^{(4,5)}$.

Despite medical recommendations, $\mathrm{Na}$ intake is still extremely high in many cultures and populations ${ }^{(1)}$. In the USA, the mean $\mathrm{Na}$ intake is approximately $4100 \mathrm{mg} / \mathrm{d}$ for men and $2750 \mathrm{mg} / \mathrm{d}$ for women, $75 \%$ of which comes from processed foods ${ }^{(1,6,7)}$. However, the lack of tools to evaluate $\mathrm{Na}$ intake is still a problem in clinical practice ${ }^{(8)}$.
The multidisciplinary team approach is effective mostly when the professionals can provide orientation based on individual needs and lifestyle ${ }^{(9)}$, but an accurate assessment of the $\mathrm{Na}$ intake of free-living persons remains a difficult and labour-intensive process. The routine assessment of the diet of a large number of individuals from a range of socioeconomic backgrounds requires a quick and simple method of estimating the intake of specific nutrients. The FFQ has been proposed as a precise measure for the evaluation of the intake of nutrients, and it has been used extensively for various purposes ${ }^{(10,11)}$. Nevertheless, few FFQ assess $\mathrm{Na}$ intake, and none has yet been developed and validated for the Brazilian population ${ }^{(12,13)}$. Therefore the aim of the present study was to develop and validate an FFQ for the 
evaluation of $\mathrm{Na}$ intake among low-income hypertensive Brazilian patients; this Brazilian version was called the Questionário de Freqüência Alimentar de alimentos com alto teor de sódio (QFASó).

\section{Study population and methods}

\section{Study population}

One hundred and thirty-two hypertensive subjects over 18 years of age, seen as outpatients in a large urban teaching hospital in south-eastern Brazil, were recruited during regular appointments. Subjects with diabetes, identifiable causes of secondary hypertension and inability to read and write were eliminated from the study, although illiterate individuals who could depend on a specific family member to register salt intake were retained. The study was performed according to university ethical committee policy, and all subjects signed a consent form.

\section{Development of the FFQ}

The FFQ was developed as recommended in the literature $^{(10)}$. A fifty-item list of high-Na foods frequently consumed by the target population of low-income Brazilians with little education was compiled from previous surveys of dietary habits of such individuals and a consultation of the literature in relation to the $\mathrm{Na}$ content of the identified items (i.e. those supplying at least $200 \mathrm{mg} \mathrm{Na} / 100 \mathrm{~g})^{(10)}$. This pre-version was evaluated by two expert dietitians to determine content validity. These experts were asked to evaluate and rank the fifty-item list of foods in relation to: (i) importance as a source of $\mathrm{Na}$; and (ii) relevance for the targeted population. Items revealing disagreement were discussed by the two experts until agreement was reached. After this analysis, six items were excluded because they were not commonly consumed by the target population; the result was the first forty-four-item version of the FFQ. This was pre-tested among fifteen patients from the targeted population and proved to be comprehensible and applicable to the studied group. The fortyfour items consisted mostly of industrialized foods such as canned dairy and meat products, condiments, snacks and fast food. Participants were asked how frequently each food was consumed during the last year, with responses ranging from $1=$ 'never' up to $7=$ 'twice or more per day'. For each food on the list, an Na conversion factor was derived from food composition tables. The conversion factor was a number between 0.01 and 1.00 and represented the amount of $\mathrm{Na}$ in $1 \mathrm{~g}$ of the food ${ }^{(14)}$. For each participant, the $\mathrm{Na}$ content of the average portion consumed was calculated by multiplying the weight of the portion (in grams) by the conversion factor. Finally, the number of milligrams of $\mathrm{Na}$ in the usual serving size was multiplied by the frequency of intake, corrected for the frequency of monthly consumption ( 0 for the score of 1 , representing never; 0.5 for the score of 2 , representing less than once monthly; 2 for a score of 3 , representing a frequency of 1-3 times monthly; 4 for a score of 4 , representing once weekly; 12 for a score of 5 , representing a frequency of 2-4 times weekly; 30 for a score of 6 , representing a frequency of once daily; and 60 for a score of 7 , representing a frequency of twice or more daily); the result was the monthly Na consumption for each item.

For foods with no published $\mathrm{Na}$ data available, the $\mathrm{Na}$ content was estimated by using known amounts in similar foods. Regional recipes were used to determine the $\mathrm{Na}$ content of frequently served dishes combining various ingredients with variable amounts of $\mathrm{Na}$. The $\mathrm{Na}$ content of the recipes was estimated by a third expert dietitian using the TACO list for the ingredients commonly used in regional recipes ${ }^{(15)}$. The following procedures were adopted to define the items to be eliminated from the final FFQ: (i) elimination of foods never consumed by more than $50 \%$ of the sample population; (ii) calculation of the sum of the scores of all subjects for the frequently consumed food items; and (iii) exclusion of those foods receiving an average score of 2 or less (total less than 264 points). Those foods retained were then tested for their contribution to overall $\mathrm{Na}$ consumption, and those not contributing more than $20 \%$ of the final $\mathrm{Na}$ intake were also excluded. The final instrument used for all analyses thus comprised fifteen items considered to be representative for the population studied.

\section{Data collection}

Participants were recruited during regular doctor visits. The administration of the FFQ was preceded by the asking of a series of questions assessing social and demographic variables; questions involving the $24 \mathrm{~h}$ recall measure were then asked. These interviews were based on meal sequence and involved a detailed assessment and description of the food consumed. Afterwards, the participants were asked about the use of discretionary salt in the household and instructed to fill out a $3 \mathrm{~d}$ dietary record starting on the fourth day after the interview; the $24 \mathrm{~h}$ urine sample was to be collected on the sixth day. For all self-report measures, the usual amount of food consumed was assessed on the basis of known home portion sizes ${ }^{(16,17)}$. On the seventh day, the patient returned for another doctor's visit at the hospital and brought the completed $3 \mathrm{~d}$ record and the $24 \mathrm{~h}$ urine sample. From the 132 subjects initially recruited, thirteen did not return the $3 \mathrm{~d}$ diet record and the $24 \mathrm{~h}$ urine sample (attrition rate of 9.8\%). A sub-sample of thirty-eight subjects with similar sociodemographic and clinical characteristics to those of the targeted population was submitted to a second interview within a $15 \mathrm{~d}$ interval to test the stability of the FFQ.

\section{Discretionary salt}

Patients were asked to rate the usual monthly salt consumption (number of $1 \mathrm{~kg}$ packages of salt consumed per month), as well as the number of persons in the household who ate at least five meals per week at home (in order to 
correct the salt consumption per person). Computation of the data from the $24 \mathrm{~h}$ recall and $72 \mathrm{~h}$ inventory measures included only the $\mathrm{Na}$ intrinsic in the foods. Added salt was computed using only the data from the discretionary salt. The US Department of Agriculture reference ( $1 \mathrm{~g}$ salt $=$ $400 \mathrm{mg} \mathrm{Na}$ ) was used to obtain the monthly and daily average of number of milligrams of $\mathrm{Na}$ per person ${ }^{(18)}$.

\section{4 b urinary $\mathrm{Na}$}

$\mathrm{Na}$ excretion was measured spectrophotometrically and converted to $\mathrm{mEq} / \mathrm{l}$. Na intake was estimated by assuming that about $86 \%$ of the total $\mathrm{Na}$ consumption of the day is excreted in the urine ${ }^{(19)}$. Subjects were carefully instructed to collect all urine produced during the $24 \mathrm{~h}$ period and to continue to drink water normally throughout the day. The percentage of $\mathrm{Na}$ intake accounted for by each self-report measure was calculated as the ratio of total dietary $\mathrm{Na}$ reported by each measure to that of the total assessment estimated from the $24 \mathrm{~h}$ urine sample, multiplied by 100 .

\section{$24 \mathrm{~b}$ recall}

This measure was assessed in a face-to-face interview in which the participants were asked to describe in as much detail as possible all the food and beverages consumed over the past $24 \mathrm{~h}$ period, including the usual portion size of these foods; they were asked to report these amounts using regionally typical utensil sizes (cups, glasses, spoons, slices and pieces) ${ }^{(20)}$.

\section{$72 \mathrm{~b}$ register}

This measure was self-administered. To maintain control of the quality of this home register, the participants were asked to record the items consumed within $30 \mathrm{~min}$ of the termination of the meal and then to record the sizes of the portions using the same measures used for recording what had been eaten when recalling consumption during the past $24 \mathrm{~h}$.

\section{Nutrient database}

Energy and nutrient intakes for both dietary assessments were calculated using the Nutwin ${ }^{\circledR}$ database software developed by the Federal University of São Paulo.

\section{Statistical analyses}

Means and standard deviations of $\mathrm{Na}$ determined using the different measures (FFQ, $24 \mathrm{~h}$ dietary recall, $3 \mathrm{~d}$ diet record, urinary $\mathrm{Na}$ excretion) were calculated. The reproducibility of the FFQ was assessed by using the kappa coefficient to test the agreement between the first and second applications of the instrument. The overall validity of the FFQ was assessed by Spearman correlation coefficients relating self-reports of salt consumption with $\mathrm{Na}$ excretion obtained from a $24 \mathrm{~h}$ urine sample; the latter was also used for the correlation of all of the items of the FFQ. A Mann-Whitney test was used to determine significant gender differences between means of salt consumption provided by the self-report methods and the $24 \mathrm{~h}$ urinary Na. Results were considered statistically significant at a two-tailed level of $0 \cdot 05$. Statistical analysis was performed by using the SAS statistical software package release $6 \cdot 12$ (SAS Institute Inc., Cary, NC, USA).

\section{Results}

The mean age of the 132 participants was $55 \cdot 5$ (sD 13.3) years. Most of them were white (78\%); the mean number of years of formal education was $5 \cdot 6(\mathrm{SD} 4 \cdot 0)$ and the mean monthly income was \$US $516 \cdot 2$ (SD 442.8). Of these 132 individuals, thirteen did not return the urinary sample $(9 \cdot 8 \%)$ and twenty-two (16.7\%) did not return the complete $72 \mathrm{~h}$ register. Nevertheless, data regarding the FFQ, the $24 \mathrm{~h}$ recall and discretionary salt were used in the analysis for the 132 subjects. There were no significant differences in sociodemographic and clinical variables between the final sample and those who dropped out. Furthermore, the 132 subjects were not different in terms of age, gender and schooling when compared with the whole population attending the ambulatory clinic ( $n$ 396) during the period of the research.

The sociodemographic and clinical characteristics of the participants are summarized in Table 1 . The $\mathrm{Na}$ intake assessed by the FFQ and the reference measures was higher for men than for women $(P<0 \cdot 05)$. No difference in discretionary salt was ascertained between genders (Table 2).

\section{Reliability}

The reliability of the FFQ was assessed according to the criterion of reproducibility. Thus, stability in relation to frequency of consumption was tested. Kappa coefficients ranged from 0.79 to $0 \cdot 98$, confirming the stability of the FFQ.

Table 1 Sociodemographic and clinical characteristics of the low-income Brazilian hypertensive patients

\begin{tabular}{|c|c|c|c|c|}
\hline & $n$ & $\%$ & & \\
\hline \multicolumn{5}{|l|}{ Gender } \\
\hline Female & 83 & $62 \cdot 9$ & & \\
\hline Male & 49 & $37 \cdot 1$ & & \\
\hline \multicolumn{5}{|l|}{ Race } \\
\hline White & 103 & $78 \cdot 0$ & & \\
\hline \multirow[t]{2}{*}{ Non-white } & 29 & $22 \cdot 0$ & & \\
\hline & Mean & SD & Median & Range \\
\hline Age (years) & $55 \cdot 5$ & $13 \cdot 3$ & $56 \cdot 0$ & $18-85$ \\
\hline Education (years) & $5 \cdot 6$ & $4 \cdot 0$ & $4 \cdot 5$ & $0-17$ \\
\hline Monthly income (\$US) & 516 & $442 \cdot 8$ & $397 \cdot 5$ & $0-2623 \cdot 5$ \\
\hline BMI $\left(\mathrm{kg} / \mathrm{m}^{2}\right)$ & $29 \cdot 4$ & $4 \cdot 8$ & 28.9 & $17 \cdot 7-39 \cdot 6$ \\
\hline Male & $29 \cdot 2$ & $5 \cdot 0$ & $29 \cdot 3$ & $19 \cdot 5-38 \cdot 1$ \\
\hline Female & $29 \cdot 5$ & $4 \cdot 6$ & $28 \cdot 9$ & $17 \cdot 7-39 \cdot 6$ \\
\hline WC (cm) & $96 \cdot 5$ & $12 \cdot 5$ & $95 \cdot 5$ & $60-129$ \\
\hline Male & $99 \cdot 2$ & $12 \cdot 7$ & $98 \cdot 0$ & $77-127$ \\
\hline Female & $94 \cdot 8$ & $12 \cdot 2$ & $94 \cdot 0$ & $60-129$ \\
\hline $\mathrm{SBP}(\mathrm{mmHg})$ & $147 \cdot 0$ & $24 \cdot 0$ & $142 \cdot 5$ & $99-220$ \\
\hline $\mathrm{DBP}(\mathrm{mmHg})$ & 86.9 & $13 \cdot 9$ & $87 \cdot 0$ & $53-135$ \\
\hline
\end{tabular}

WC, waist circumference; SBP, systolic blood pressure; DBP, diastolic blood pressure. 
Table 2 Dietary intake of sodium from the FFQ and self-report methods, biological marker of sodium intake, and mean differences in intake between men and women among the low-income Brazilian hypertensive patients

\begin{tabular}{|c|c|c|c|c|c|c|c|c|c|}
\hline & \multirow[b]{2}{*}{ Mean } & \multirow[b]{2}{*}{ SD } & \multirow[b]{2}{*}{ Median } & \multirow[b]{2}{*}{ Range } & \multicolumn{2}{|c|}{ Men } & \multicolumn{2}{|c|}{ Women } & \multirow[b]{2}{*}{$P$ value } \\
\hline & & & & & Mean & SD & Mean & SD & \\
\hline Na consumption from $24 \mathrm{~h}$ urinary $\mathrm{Nat}(\mathrm{mg} \mathrm{Na} / \mathrm{d})$ & 5384 & 2402 & 5086 & $734-12756$ & 6125 & 2636 & 4917 & 2131 & 0.02 \\
\hline Discretionary salt (mg Na/d) & 2902 & 1882 & 2444 & $740-13333$ & 2740 & 1451 & 2998 & 2098 & NS \\
\hline $\begin{array}{l}\mathrm{FFQ}(\mathrm{mg} \mathrm{Na} / \mathrm{d}) \\
\quad+\text { discretionary salt added } \ddagger(\mathrm{mg} \mathrm{Na} / \mathrm{d})\end{array}$ & $\begin{array}{l}2191 \\
5093\end{array}$ & $\begin{array}{r}2681 \\
267\end{array}$ & $\begin{array}{l}1175 \\
4117\end{array}$ & $\begin{array}{r}78-12237 \\
1047-15568\end{array}$ & $\begin{array}{l}3111 \\
5851\end{array}$ & $\begin{array}{l}3328 \\
3419\end{array}$ & $\begin{array}{l}1648 \\
4646\end{array}$ & $\begin{array}{l}2048 \\
2772\end{array}$ & $\begin{array}{l}0.007 \\
0.05\end{array}$ \\
\hline $\begin{array}{l}24 \mathrm{~h} \text { recall }(\mathrm{mg} \mathrm{Na} / \mathrm{d}) \\
+ \text { discretionary salt added }(\mathrm{mg} \mathrm{Na} / \mathrm{d})\end{array}$ & $\begin{array}{l}1052 \\
3954\end{array}$ & $\begin{array}{l}926 \\
191\end{array}$ & $\begin{array}{r}779 \\
3582\end{array}$ & $\begin{array}{c}50-6475 \\
1113-15398\end{array}$ & $\begin{array}{l}1297 \\
4037\end{array}$ & $\begin{array}{l}1186 \\
2184\end{array}$ & $\begin{array}{r}907 \\
3905\end{array}$ & $\begin{array}{r}700 \\
2219\end{array}$ & $\begin{array}{r}0 \cdot 05 \\
\text { NS }\end{array}$ \\
\hline $\begin{array}{l}72 \mathrm{~h} \text { register (median of } 3 \mathrm{~d} ; \mathrm{mg} \mathrm{Na} / \mathrm{d}) \\
+ \text { discretionary salt added }(\mathrm{mg} \mathrm{Na} / \mathrm{d})\end{array}$ & $\begin{array}{l}1048 \\
3859\end{array}$ & $\begin{array}{r}679 \\
1856\end{array}$ & $\begin{array}{r}895 \\
3378\end{array}$ & $\begin{array}{c}22-5061 \\
1343-13846\end{array}$ & $\begin{array}{l}1141 \\
3967\end{array}$ & $\begin{array}{r}628 \\
1763\end{array}$ & $\begin{array}{r}991 \\
3793\end{array}$ & $\begin{array}{r}707 \\
1921\end{array}$ & $\begin{array}{l}\text { NS } \\
\text { NS }\end{array}$ \\
\hline
\end{tabular}

*Mann-Whitney test.

†Na consumption estimated from the urinary $\mathrm{Na}$ excretion ${ }^{(17)}$

‡Discretionary $\mathrm{Na}$ summed to the $\mathrm{Na}$ given by the specific method.

\section{Validity}

There was no correlation between urinary $\mathrm{Na}$ excretion, the FFQ and the $24 \mathrm{~h}$ recall for the general sample, although significant correlations had been observed when methods were summed up $(24 \mathrm{~h}$ recall + discretionary salt + FFQ; $0 \cdot 32, P=0 \cdot 01$ ). Spearman correlation coefficients with the $72 \mathrm{~h}$ register + discretionary salt $+\mathrm{FFQ}$ (first and second day) were 0.19 and $0 \cdot 20(P<0 \cdot 05)$ for the sample as a whole and, for the second day, $0 \cdot 27(P=0 \cdot 03)$ for the sub-sample of women. The FFQ alone, as well as the other self-reported measures, revealed no significant correlations with $24 \mathrm{~h}$ urinary $\mathrm{Na}$; however, when discretionary salt was added, the correlations were significant for the $24 \mathrm{~h}$ recall in the sub-sample of women. Furthermore, for the sample as a whole, Spearman correlation coefficients were significant when the FFQ was included with the self-report measures already corrected for discretionary salt (Table 3).

The percentage of total $\mathrm{Na}$ intake provided by each of the self-report measures was calculated on the basis of the $24 \mathrm{~h}$ urinary $\mathrm{Na}$, as shown in Table 4 . The $24 \mathrm{~h}$ recall and the FFQ alone provided a low estimation of the $\mathrm{Na}$ intake $(23.9 \%$ and $48.9 \%)$, but inclusion of discretionary salt improved this to $87 \cdot 2 \%$ and $112 \cdot 2 \%$ of the value registered by the assessment of $24 \mathrm{~h}$ urinary $\mathrm{Na}$.

The correlation of each of the final fifteen items of the FFQ was tested against the total $\mathrm{Na}$ consumption estimated by the instrument. Three items were found to correlate significantly with total $\mathrm{Na}$ intake: chicken sausage $(0 \cdot 32$, $P=0 \cdot 02$ ), type one seasoning (industrialized blend of seasonings of salt and added spices; 0.95, $P<0 \cdot 001$ ) and type two seasoning (beef flavour bouillon tablet; 0.51, $P<0 \cdot 001$ ).

\section{Discussion}

Data are lacking about the sources of $\mathrm{Na}$ in the Brazilian diet. $\mathrm{Na}$ intake by hypertensive subjects, however, is a cause of major concern among health professionals; moreover, there is a lack of validated instruments and
Table 3 Spearman correlation coefficients of the FFQ and the selfreport methods against urinary sodium excretion for the general sample, women and men sub-samples of the low-income Brazilian

\begin{tabular}{|c|c|c|c|}
\hline & General sample & Women & Men \\
\hline Discretionary salt & NS & $\begin{array}{l}0.30 \\
0.02\end{array}$ & NS \\
\hline FFQ & NS & NS & NS \\
\hline $\begin{array}{l}24 \mathrm{~h} \text { recall } \\
+ \text { discretionary salt } \\
+ \text { discretionary salt }+\mathrm{FFQ}\end{array}$ & $\begin{array}{l}\text { NS } \\
0.18^{\star} \\
0.06 \dagger \\
0.23 \\
0.02\end{array}$ & $\begin{array}{c}\text { NS } \\
0.32 \\
0.01 \\
0.31 \\
0.01\end{array}$ & $\begin{array}{l}\text { NS } \\
\text { NS }\end{array}$ \\
\hline $\begin{array}{l}72 \text { h register - day } 1 \\
+ \text { discretionary salt } \\
\quad+\text { discretionary salt }+F F Q\end{array}$ & $\begin{array}{l}\text { NS } \\
\text { NS } \\
0 \cdot 19 \\
0 \cdot 05\end{array}$ & $\begin{array}{l}\text { NS } \\
\text { NS } \\
0 \cdot 23 \\
0 \cdot 06\end{array}$ & $\begin{array}{l}\text { NS } \\
\text { NS } \\
\text { NS }\end{array}$ \\
\hline $\begin{array}{l}72 \text { h register }- \text { day } 2 \\
+ \text { discretionary salt }\end{array}$ & $\begin{array}{l}\text { NS } \\
\text { NS }\end{array}$ & $\begin{array}{l}\text { NS } \\
0 \cdot 23 \\
0 \cdot 06\end{array}$ & $\begin{array}{l}\text { NS } \\
\text { NS }\end{array}$ \\
\hline + discretionary salt + FFQ & $\begin{array}{l}0.20 \\
0.04\end{array}$ & $\begin{array}{l}0.27 \\
0.03\end{array}$ & NS \\
\hline $\begin{array}{l}72 \mathrm{~h} \text { register }- \text { day } 3 \\
+ \text { discretionary salt } \\
+ \text { discretionary salt }+\mathrm{FFQ}\end{array}$ & $\begin{array}{l}\text { NS } \\
\text { NS } \\
\text { NS }\end{array}$ & $\begin{array}{l}0 \cdot 22 \\
0 \cdot 80 \\
\text { NS } \\
\text { NS }\end{array}$ & $\begin{array}{l}\text { NS } \\
\text { NS }\end{array}$ \\
\hline $\begin{array}{l}72 \mathrm{~h} \text { register } \\
+ \text { discretionary salt } \\
\quad+\text { discretionary salt }+\mathrm{FFQ}\end{array}$ & $\begin{array}{l}\text { NS } \\
\text { NS } \\
\text { NS }\end{array}$ & $\begin{array}{l}\text { NS } \\
\text { NS } \\
0 \cdot 25 \\
0.05\end{array}$ & $\begin{array}{l}\text { NS } \\
\text { NS } \\
\text { NS }\end{array}$ \\
\hline
\end{tabular}

${ }^{*}$ Correlation coefficient.

$+P$ value.

measures for the assessment of habitual dietary Na intake, which hinders the evaluation of individual dietary $\mathrm{Na}$ patterns in clinical practice ${ }^{(21,22)}$. Development and validation of tools to access $\mathrm{Na}$ consumption is still a challenge. Assessing $\mathrm{Na}$ intake more accurately implies identification of the sources of $\mathrm{Na}$ in the standard diet, yet this is different from the situation for other nutrients which are supplied largely by intrinsic nutrients in specific foods ${ }^{(8)}$. Na constitutes a part of almost all fresh foods, and it is a major component of industrialized, 
Table 4 Percentage of consumption given by the self-reported methods with and without the addition of discretionary salt in relation to the consumption estimated by urinary sodium excretion among the low-income Brazilian hypertensive patients

\begin{tabular}{lrrr}
\hline & \multicolumn{3}{c}{$\begin{array}{c}\text { \% of } \mathrm{Na} \text { intake estimated by } \\
\text { urinary Na }\end{array}$} \\
\cline { 2 - 4 } Method & Mean & \multicolumn{1}{c}{ SD } & Median \\
\hline Discretionary salt & $63 \cdot 3$ & $48 \cdot 4$ & $51 \cdot 7$ \\
FFQ & $48 \cdot 9$ & $72 \cdot 4$ & $19 \cdot 3$ \\
$\quad+$ discretionary salt & $112 \cdot 2$ & $101 \cdot 6$ & $82 \cdot 6$ \\
24h recall & $23 \cdot 9$ & $24 \cdot 7$ & $15 \cdot 2$ \\
$\quad+$ discretionary salt & $87 \cdot 2$ & $63 \cdot 7$ & $72 \cdot 4$ \\
$\quad+$ discretionary salt + FFQ & $136 \cdot 1$ & $114 \cdot 2$ & $104 \cdot 9$ \\
\hline
\end{tabular}

canned and pre-prepared foods. Moreover, table salt and that added when preparing foods are also an important source of $\mathrm{Na}$ in the individual diet ${ }^{(1,6,8)}$. Therefore, in order to estimate $\mathrm{Na}$ consumption, it is necessary to consider all different sources of dietary $\mathrm{Na}$. In the present study, we have developed and evaluated the validity of an FFQ (QFASó) to provide an instrument to furnish rapid information about the consumption of foods known to be sources of large amounts of $\mathrm{Na}$ and which cannot be assessed by other measures.

The questionnaire was validated using the self-report measures of $24 \mathrm{~h}$ recall and $72 \mathrm{~h}$ register (both alone and corrected with the inclusion of discretionary salt), as well as a biomarker ( $24 \mathrm{~h}$ urinary Na). The method of $24 \mathrm{~h}$ recall is simple and easy to use, and can be administered by the researcher; it can provide results of great accuracy in relation to frequency and portions consumed. However, an individual's memory is limited. The $72 \mathrm{~h}$ record tends to be more accurate because it is based on immediate registration of consumption, thus eliminating the memory bias ${ }^{(17)}$, but depends on the commitment of the subject as well as requiring a certain level of literacy ${ }^{(13,19)}$. Urinary $\mathrm{Na}$ is considered to be the ideal measure for estimation of $\mathrm{Na}$ consumption although it does not provide information about the quantity of nutrients consumed, nor what dietary habits are involved, so it is of less help in planning educational intervention ${ }^{(23,24)}$.

In this matter, the FFQ was a useful tool to highlight the contribution of some items such as seasonings, whose information is not accessed by any other method and was found to be a major source of $\mathrm{Na}$ for these Brazilians. The higher correlations involved for the subset of women reflects the results of various studies which have shown FFQ to correlate with the food habits of women ${ }^{(25-27)}$; this may be due to the fact that women are generally responsible for the purchase of food and the preparation of meals, which may make them more likely to be able to estimate their consumption and dietary habits than are men.

A significant correlation between self-report measures and urinary $\mathrm{Na}$ was obtained only when discretionary $\mathrm{Na}$ was included. This can be explained by the fact that the $24 \mathrm{~h}$ and $72 \mathrm{~h}$ measures do not consider the salt added to food, neither before nor after preparation, yet for this population discretionary salt is an important source of dietary $\mathrm{Na}$.

Furthermore, our data suggest that the various measures used ( $24 \mathrm{~h}$ recall, $72 \mathrm{~h}$ register, FFQ, discretionary salt) may tap different dimensions of the actual total intake of $\mathrm{Na}$, since the sum of the three measures correlated better with $24 \mathrm{~h}$ urinary $\mathrm{Na}$ than did any of them alone. The $24 \mathrm{~h}$ recall and the $72 \mathrm{~h}$ register evaluated the intake of participants in just a brief period of time, and it did not include some of the sources of $\mathrm{Na}$ assessed with the FFQ, nor did it evaluate the regular use of discretionary salt.

Various studies have limited the evaluation of diet to one or two methods of assessment ${ }^{(28)}$, and this may introduce a critical bias when evaluating $\mathrm{Na}$ intake. The use of three measures has proved more efficient for the triangulation of $\mathrm{Na}$ intake ${ }^{(29,30)}$.

Another contribution of the present study was the inclusion of low-income individuals of marginal literacy, as such people tend to face greater difficulty in filling out questionnaires ${ }^{(11)}$. Even though limited literacy was included as a criterion for the elimination of potential subjects, we were able to collect information from a sample with very low literacy levels, with $50 \%$ of them having only 4.5 years or less of formal education. Such a group truly represents the population of low income and marginal literacy targeted here.

We conclude that the FFQ developed is a reliable and valid method for assessing $\mathrm{Na}$ intake, even though it should not be used alone to assess overall $\mathrm{Na}$ intake. The application of this validated FFQ, when used in conjunction with other measures such as $24 \mathrm{~h}$ recall and the use of discretionary salt, can be extremely helpful in epidemiological studies evaluating $\mathrm{Na}$ consumption and its relation to disease in low-income Brazilians.

\section{Acknowledgements}

The study was supported by Foundation for the Support of Research of the State of São Paulo (FAPESP). None of the authors had any conflicts of interest. M.-C.S.F.-S., M.-C.J.B.G. and W.N. contributed to the conception and design of the study. M.-C.S.F.-S. supervised the experiment and the data collection. R.C.M.R., K.G.F. and M.L.S. participated in the analysis of the results, and M.-C.S.F.-S. and M.-C.J.B.G. interpreted the data and wrote the manuscript. P.C.C. contributed to the FFQ development and participated in the revision of the manuscript. The authors would like to thank all participants in the study; acknowledge the contribution of the staff of the outpatient area of the Hypertension and Nutrition Department of the University Hospital; and thank the anonymous reviewers for their helpful comments.

\section{References}

1. Joint National Committee on Prevention, Detection, Evaluation, and Treatment of High Blood Pressure (2003) 
The seventh report of the Joint National Committee on Prevention, Detection, Evaluation, and Treatment of High Blood Pressure. JAMA 289, 2560-2572.

2. Knoops KT, de Groot LC, Kromhout D, Perrin AE, MoreirasVarela O, Menotti A \& van Staveren WA (2004) Mediterranean diet, lifestyle factors, and 10-year mortality in elderly European men and women: the HALE project. JAMA 292, 1433-1439.

3. Kromhout D, Menotti A, Bloemberg B et al. (1995) Dietary saturated and trans fatty acids and cholesterol and 25-year mortality from coronary heart disease: the Seven Countries Study. Prev Med 24, 308-315.

4. Trichopoulou A, Costacou T, Bamia C \& Trichopoulos D (2003) Adherence to a Mediterranean diet and survival in a Greek population. N Engl J Med 348, 2599-2608.

5. Hu FB, Rimm EB, Stampfer MJ, Ascherio A, Spiegelman D \& Willett WC (2000) Prospective study of major dietary patterns and risk of coronary heart disease in men. $\mathrm{Am} \mathrm{J}$ Clin Nutr 72, 912-921.

6. Cutler JA \& Roccella EJ (2006) Salt reduction for preventing hypertension and cardiovascular disease: a population approach should include children. Hypertension $\mathbf{4 8}$, 818-819.

7. Cutler JA (1997) Dietary sodium reduction: is there cause for concern? J Am Coll Nutr 16, 192-203.

8. Cutler JA, Follmann D \& Allender PS (1997) Randomized trials of sodium reduction: an overview. Am J Clin Nutr $\mathbf{6 5}$, 2 Suppl., 642S-651S.

9. Bosworth HB, Olsen MK, McCant F, Harrelson M, Gentry P, Rose C, Goldstein MK, Hoffman BB, Powers B \& Oddone EZ (2007) Hypertension Intervention Nurse Telemedicine Study (HINTS): testing a multifactorial tailored behavioral/ educational and a medication management intervention for blood pressure control. Am Heart J 153, 918-924.

10. Burley V \& Cade J (2000) Consensus document on the development, validation and utilization of food frequency questionnaires. In The Fourth International Conference on Dietary Assessment Methods. Int J Epidemiol 29, $17-20$.

11. Coates RJ \& Monteilh CP (1997) Assessments of foodfrequency questionnaires in minority populations. $A m J$ Clin Nutr 65, 4 Suppl., 1108S-1115S.

12. Charlton KE, Steyn K, Levitt NS, Jonathan D, Zulu JV \& Nel JH (2008) Development and validation of a short questionnaire to assess sodium intake. Public Health Nutr 11, 83-94.

13. Sasaki S, Ishihara J \& Tsugane S; JPHC (2003) Validity of a self-administered food frequency questionnaire in the 5-year follow-up survey of the JPHC Study Cohort I to assess sodium and potassium intake: comparison with dietary records and 24-hour urinary excretion level. J Epidemiol 13, 1 Suppl., S102-S105.

14. Coulibaly A, Turgeon O'Brien H \& Galibois I (2008) Validation of an FFQ to assess dietary protein intake in type 2 diabetic subjects attending primary health-care services in Mali. Public Health Nutr (Epublication ahead of print version).

15. Núcleo de Estudos e Pesquisas em Alimentação/Universidade Estadual de Campinas (2006) TACO - Tabela brasileira de composição de alimentos, 2nd ed. Campinas, São Paulo: NEPA/UNICAMP; available at http://www. unicamp.br/nepa/taco/contar/taco_versao2.pdf
16. Buzzard M (1998) 24-Hour dietary recall and food record methods. In Nutritional Epidemiology, 2nd ed., pp. 51-67 [WC Willett, editor]. New York: Oxford University Press.

17. Welten DC, Carpenter RA, McPherson RS, Brodney S, Douglass D, Kampert JB \& Blair SN (2000) Comparison of a dietary record using reported portion size versus standard portion size for assessing nutrient intake. Public Health Nutr 3, 151-158.

18. US Department of Agriculture, Agricultural Research Service, Dietary Guidelines Advisory Committee (2003) The Report of the Dietary Guidelines Advisory Committee on Dietary Guidelines for Americans, 2005. http:// www.health.gov/dietaryguidelines/dga2005/report/HTML/ D7_Fluid.htm (accessed February 2006).

19. Holbrook JT, Patterson KY, Bodner JE, Douglas LW, Veillon C, Kelsay JL, Mertz W \& Smith JC Jr (1984) Sodium and potassium intake and balance in adults consuming selfselected diets. Am J Clin Nutr 40, 786-793.

20. Kumanyika S, Tell GS, Shemanski L, Martel J \& Chinchilli VM (1997) Dietary assessment using a picture-sort approach. Am J Clin Nutr 65, 4 Suppl., 1123S-1239S.

21. Dickinson BD \& Havas S; Council on Science and Public Health, American Medical Association (2007) Reducing the population burden of cardiovascular disease by reducing sodium intake: a report of the Council on Science and Public Health. Arch Intern Med 167, 1460-1468.

22. Lichtenstein AH, Appel LJ, Brands M et al. (2006) Diet and lifestyle recommendations revision 2006: a scientific statement from the American Heart Association Nutrition Committee. Circulation 114, 82-96.

23. Newby PK, Hu FB, Rimm EB, Smith-Warner SA, Feskanich D, Sampson L \& Willett WC (2003) Reproducibility and validity of the Diet Quality Index Revised as assessed by use of a food-frequency questionnaire. Am J Clin Nutr 78, 941-949.

24. Laviolle B, Froger-Bompas C, Guillo P, Sevestre A, Letellier C, Pouchard M, Daubert J-C \& Paillard F (2005) Relative validity and reproducibility of a 14-item semi-quantitative food frequency questionnaire for cardiovascular prevention. Eur J Cardiovasc Prev Rehabil 12, 587-595.

25. Thompson FE, Midthune D, Subar AF, Kipnis V, Kahle LL \& Schatzkin A (2007) Development and evaluation of a short instrument to estimate usual dietary intake of percentage energy from fat. J Am Diet Assoc 107, 760-767.

26. Wang L, Gaziano JM, Liu S, Manson JE, Buring JE \& Sesso HD (2007) Whole- and refined-grain intakes and the risk of hypertension in women. Am J Clin Nutr 86, 472-479.

27. Ubeda N, Basagoiti M, Alonso-Aperte E \& Varela-Moreiras G (2007) Dietary food habits, nutritional status and lifestyle in menopausal women in Spain. Nutr Hosp 22, 313-321.

28. Zhang L, Miyaki K, Araki J, Song Y, Kimura T, Omae K \& Muramatsu M (2006) Interaction of angiotensin Iconverting enzyme insertion-deletion polymorphism and daily salt intake influences hypertension in Japanese men. Hypertens Res 29, 751-758.

29. Holmes B, Dick K \& Nelson M (2008) A comparison of four dietary assessment methods in materially deprived households in England. Public Health Nutr 11, 444-456.

30. Ocké MC \& Kaaks RJ (1997) Biochemical markers as additional measurements in dietary validity studies: application of the method of triads with examples from the European Prospective Investigation into Cancer and Nutrition. Am J Clin Nutr 65, 4 Suppl., 1240S-1245S. 